\title{
SECOND INTERNATIONAL CONFERENCE ON INSURANCE SOLVENCY
}

In June 1986 a Conference was convened in Philadelphia, USA at which current research concerning the solvency of insurance companies was discussed. The Conference was distinctive in its international coverage and its multidisciplinary nature. Papers were presented from the perspective of accountants, actuaries and economists and the subject was approached from a wide variety of angles.

In the light of the success of this Conference, the convenors felt that there would be interest in and support for further Conferences specializing in solvency research at suitable intervals. The Second International Conference on Insurance Solvency was organized, therefore, to take place in Brighton on 25-27 May 1988. There were 59 participants, from 13 countries. A full programme of 7 sessions was arranged, at which 15 papers were presented.

The Conference was sponsored by 16 companies, firms and organizations, who contributed over $£ 15,000$ for the purpose of underwriting the travel expenses of those who would otherwise have found it difficult to attend the meeting. The availability of these funds enabled a good number of overseas participants to attend.

A major benefit of the Conference was to bring together academic researchers and pratically-orientated actuaries and others to discuss the latest developments in research related to insurance solvency. Much attention has been paid in the United States of America in recent years to the use of the Capital Asset Pricing Model and Option Pricing Models in determining fair rates of return for pricing purposes and in examining capital structures and requirements. These ideas are not familiar to most actuaries, nor do they have the same currency in Europe and elsewhere in the world. However, leading exponents of these ideas were able to present them at the Conference and allow them to be subjected to informed discussion.

D'ARCY and GARVEN (1988), and also Venezian (1988), presented some practical results of the experience over recent years of using the Capital Asset Pricing Model (CAPM) in premium rating. Cummins (1988) presented the latest type of model to emerge from the CAPM stable, which uses stochastic diffusion processes. This is a similar approach to that used in BLACK and SCHOLES (1973), where the theory of option pricing was first presented. Whereas CAPM models tend to assume that the risk of default by the insurance company is negligible, diffusion-based models permit the risk of default to be taken into account directly. Cummins (1988) looked at the general question of the capital structure of an insurance company and the implications that this has for the determination of fair profits.

Another interesting area of development amongst financial economists is looking at ways of modelling the demand side of insurance purchasing. DOHERTY and SCHLESINGER (1988) examined how the risk of default of an 
insurance company might be taken into account by consumers in the insurance market and how it might influence their behaviour.

In the United Kingdom, the lead on insurance solvency research has been taken by the Solvency Working Party of the General Insurance Study Group of the Institute of Actuaries. Their latest work was presented by DAYKIN and HEY (1988), extending previous work on the use of cash flow simulation modelling into the field of modelling the dynamics of an insurance company as a going concern. This work emphasises the importance of modelling future cash flows in order to gain an appreciation of what is really going on in an insurance company's business, and brings together assets and liabilities in a coherent way. Simulation enables the variable nature of many of the quantities involved to be modelled directly and the model structure permits the impact of many different parameters to be studied.

Although starting more from the CAPM perspective, PAULSON (1988) described work along quite similar lines to the UK Solvency Working Party, employing cash flow modelling ideas and simulation.

Much of the development of classical risk theory approaches to the solvency of general insurance companies has taken place in Finland. Three members of the Finnish Working Party on Solvency, Pentikäinen, Rantala and Pesonen, were present at the Conference, but did not present a formal paper. They were able to announce, however, their forthcoming book "On the Solvency and Financial Strength of Insurers" (PENTIKÄINEN et al. (1988)), which will contain a review of all their recent work. From Denmark RAMLAU-HANSEN (1988) was in the same tradition, focussing on the evaluation of solvency margin requirements, and from an Australian perspective TAYLOR (1988) explored some of the latest developments in this areas using control theory, in an analysis of underwriting cycles and their effects on insurance solvency.

In spite of considerable developments in the analysis of solvency and financial strength in recent years, methods of assessing financial strength using various formulae derived from accounting information are still popular in many parts of the world and are used by supervisors in a number of countries for early warning indicators. NIELSON (1988) presented some ideas for using a new measure of "capacity" as a solvency indicator for property-casualty companies, whilst BAR Niv and Hershbarger (1988) put forward some ideas for extending the list of early warning indicators in the field of life insurance.

Life insurance aspects were rather underrepresented in the papers presented at the Conference, the only other paper on life insurance being from BRENDER (1988) on developments in testing the solvency of life insurers in Canada. However, this provided some interesting resonances with the work of the UK Solvency Working Party, since the Canadians are moving towards a system involving actuarial reports on scenario testing. The proposal as it stands is for a number of deterministic scenarios to be explored, to test the resilience of an insurer's financial condition to adverse developments in a variety of different factors. However, the possibility remains of moving towards stochastic simulation if adequate models can be devised to represent the stochastic elements, for example the behaviour of the asset portfolio. 
MCGUINNESS (1988) looked at the problems posed for the solvency of insurance companies by the possibility of a catastrophic earthquake or similar event and suggested some practical solutions which would involve action on the political and fiscal level.

The remaining papers considered a miscellany of topics, including distributions (BoOKstaber and MCDonald, 1988), loss reserves (MEYERs, 1988 and ButsiC, 1988) and reinsurance (Von EIJE, 1988).

One of the aims of the Conference was to expose actuaries to the concepts of financial economics and financial economists to the views of actuaries. In this respect the Conference was highly successful, although there remains a long way to go to bring the different schools of thought closer together. The hope is that further research will help in this process of drawing on the best in the different disciplines and will carry forward our understanding of the insurance process and the key requirements for managing it successfully.

With much work clearly remaining to be done in this field, the convenors are hoping to arrange a further Conference in Amsterdam in 1991. The aim for that Conference would be to encourage further practically-orientated research by suggesting particular areas in which papers would be welcomed.

The Brighton Conference was dedicated to Professor Teivo Pentikäinen, an internationally renowned authority in classical risk theory and in the study of solvency. At the concluding dinner of the Conference, a plaque was presented to Professor Pentikäinen to commemorate his important work in this field.

The proceedings of the Conference will be published in early 1989 by Kluwer Academic Publishers. The proceedings of the Philadelphia Conference in 1986 have recently been published in two volumes. The first of these, entitled "Classical Insurance Solvency Theory" (Cummins and DERrIG, 1988), includes seminal papers by Pentikäinen and by Taylor and Buchanan on the problems of solvency and the classical risk theory approaches to their solution. Volume 2, entitled "Financial Models of Insurance Solvency" (Cummins and DERRIG, 1988a), includes papers on cash flow simulation modelling and contributions from the viewpoint of the modern theory of financial economics.

CHRIS DAYKIN

September 1988.

\section{REFERENCES}

BAK NIV, R. and Hershbarger, R.A. (1988). Classifying financial distress in the life insurance industry.

Black, F. and Scholes, M. (1973). The pricing of options and corporate liabilities. Journal of Political Economy, 81, 637657.

BoOkstaber, R. M. and MCDONALD, J.B. (1988). A general distribution for describing security price returns.

Brender, A. (1988). Testing the solvency of life insurers.

Butsic, R.P. (1988). Determining the proper interest rate for loss reserve discounting: an economic approach. 
Cummins, J.D. (1988). Capital structure and fair profits in property-liability insurance.

Cummins, J.D. and Derrig, R. A. (editors) (1988). Classical Insurance Solvency Theory. Kluwer Academic Publishers, Norwell M.A.

Cummins, J.D. and Derrig, R. A. (editors) (1988a). Financial Models of Insurance Solvency. Kluwer Academic Publishers, Norwell M.A.

D'ARCY, S.P. and GARVEN, J. R. (1988). A synthesis of property-liability pricing techniques.

DAYKIN, C. D. and HEY, G. B. (1988). A management model of a general insurance company using simulation techniques.

DoherTy, N.A. and SCHLesinger, H. (1988). Rational insurance purchasing: consideration of contract non-performance.

MCGUINNESS, J. S. (1988). Income taxation as realistic time-and-distance catastrophe reserving.

Meyers, G. (1988). Safety loadings for loss reserves.

Nielson, N.L. and Grace, E.V. (1988). Capacity as an indicator of insurer solvency.

PAULSON, A.S. (1988). Assessment via simulation of certain financial rate of return models, CAPM and duration matching (oral presentation).

Pentikäinen, T., Bonsdorff, H., Pesonen, M. et al (1988). On the solvency and financial strength of insurers : a progress report. (Draft presented at the Special Meeting on the Capital Needs of Insurance Companies, Helsinki, July 1988).

Ramlau-Hansen, H. (1988). Solvency study in non-life insurance: solvency margin requirements.

TAYLOR, G.C. (1988). An analysis of underwriting cycles in relation to insurance pricing and solvency.

VENEZIAN, E.C. (1988). Effect of serially autocorrelated profit margins on the solvency of insurers.

VoN EIJE, J.H. (1988). The value of ceded reinsurance. 